\title{
Development of different damage pathways in Norway lobster (Nephrops norvegicus) stored under different chilling systems
}

\author{
Vanesa Losada ${ }^{1}$, Óscar Rodríguez ${ }^{2}$, José M. Miranda ${ }^{2}$, Jorge Barros- \\ Velázquez ${ }^{2}$ and Santiago P. Aubourg,**
}

${ }^{1}$ Department of Seafood Chemistry; Institute for Marine Research (CSIC), C/ Eduardo Cabello 6, 36208-Vigo (Galicia, Spain)

${ }^{2}$ Department of Analytical Chemistry, Nutrition and Food Science, School of Veterinary Sciences, University of Santiago de Compostela, 27002-Lugo (Galicia, Spain)

*Correspondent: Fax: +34 986 292762; e-mail: saubourg@iim.csic.es 


\begin{abstract}
Slurry ice is a biphasic system that has recently shown a number of advantages when employed as a chilling medium for fish species. Its use for a crustacean species of high commercial value -namely Norway lobster (Nephrops norvegicus)- was evaluated in parallel to traditional flake icing. Quality parameters related to microbial spoilage and biochemical breakdown (aerobe and psychrotroph counts, $\mathrm{pH}, \mathrm{K}$ value, total volatile amines, trimethylamine, free fatty acids, and non-enzymatic browning reactions) were assessed and compared with sensory (carapace, eyes, gills, odour and flesh) acceptability. Storage in slurry ice produced a significant $(\mathrm{p}<0.05)$ inhibitory effect on both microbial growth (as determined by aerobes, psychrotrophs and volatile amines) and autolysis breakdown (as determined by $\mathrm{K}$ values and the release of free fatty acids) in comparison with the flake ice batch. In contrast, an enhancement effect of slurry ice on carapace browning was observed as a result of enzymatic browning development. Slurry ice batch also showed a more intense non-enzymatic browning reaction in the lipid extract of the edible flesh. With a view to limiting both browning effects, the incorporation of an anti-melanosis agent in the liquid phase of the slurry ice system is envisaged.
\end{abstract}

Running Title: Quality loss in chilled lobster

Keywords: Norway lobster, chilling, flake and slurry ice, sensorial, microbiological and chemical determinations 


\section{INTRODUCTION}

The crustacean fishery affords to products of great economic importance in many countries worldwide ${ }^{1}$. However, crustacean species have proved to have a very short period of shelf life as a result of several factors, such as being of small size, not being gutted, and showing a high content of non-protein nitrogenous (NPN) compounds, polyunsaturated fatty acids (PUFAs) and melanin pigment ${ }^{2,3}$. As a consequence of this, post-mortem autolytic changes, microbial spoilage and melanosis reactions have been shown to have a detrimental effect on quality after capture ${ }^{4-6}$. With a view to slowing down the mechanisms involved in quality loss, crustacean species should be chilled immediately after capture. Thus, different preservation methods such as traditional flake icing ${ }^{7}$, refrigerated sea water $^{8}$, storage under a modified atmosphere ${ }^{9}$, immersion in brine solutions ${ }^{10}$ and the incorporation of chemical preservative agents ${ }^{11}$ have been successfully applied to aquatic food products.

Recently, slurry ice -also known as liquid ice or flow ice- has been reported to be a promising technique for the chilled preservation of aquatic food products ${ }^{12}$. Among others, the main features of slurry ice are: (i) storage of the material at a temperature slightly below $0^{\circ} \mathrm{C}$, (ii) a fast chilling rate, due to its high heat-exchange capacity, (iii) reduced physical damage caused to the food surface by the spherical microscopic particles characteristic of slurry ice, and (iv) complete coverage of the surface of the material by the slurry ice mixture, this protecting the it from the action of oxygen.

Previous studies have reported good results in the application of slurry ice systems to farmed sea bream (Sparus aurata) and turbot (Psetta maxima) ${ }^{13,14}$ and to wild albacore (Thunnus alalunga), hake (Merluccius merluccius), and sardine (Sardina

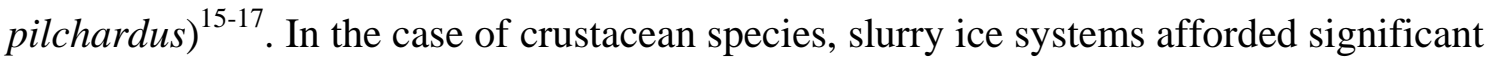


advantages during the chilled storage of Australian prawn (Penaeus monodon) ${ }^{18}$ and pink shrimp (Perapenaeus longirostris) ${ }^{19}$.

The present study focuses on Norway lobster (Nephrops norvegicus), since this aquatic food product exhibits a remarkably high commercial value in many European countries $^{20}$. Thus, the commercialisation of chilled Norway lobster has increased in recent years in response to increasing consumer demand. In the present work, the application of slurry ice to the chilled storage of this crustacean species was studied and evaluated in parallel to traditional flake ice storage. The evolution of quality was assessed by evaluating a number of microbial and biochemical parameters indicative of spoilage, the results being compared with sensory acceptability.

\section{MATERIALS AND METHODS}

\section{Chilling systems}

A slurry ice prototype (FLO-ICE ${ }^{\mathrm{TM}}$, Kinarca S.A.U., Vigo, Spain) was used. The composition of the liquid-ice binary mixture was $40 \%$ ice/ $60 \%$ water, prepared from filtered seawater with a $3.3 \% \mathrm{NaCl}$ content. The temperature of the liquid-ice mixture was $-1.5^{\circ} \mathrm{C}$. Flake ice was prepared from tap water by means of an Icematic F100 Compact device (CASTELMAC SPA, Castelfranco, Italy). The temperature of the flake ice was $+0.5{ }^{\circ} \mathrm{C}$. Both temperatures were monitored during storage. The lobster specimens were surrounded by an equal weight of slurry or flake ice, and stored in a refrigerated room at $+2^{\circ} \mathrm{C}$. When required, the flake ice and the slurry ice mixture were renewed. 
$\underline{\text { Raw material, processing and sampling }}$

A total of 135 cultivated Norway lobster (Nephrops norvegicus) specimens (carapace length 8-11 cm) were obtained alive at a local market in December 2004 and then sacrificed in a water-ice mixture at our laboratory. Fifteen specimens were separated (three groups of five specimens each; $n=3$ ) for study as initial material on day 0. The remaining 120 specimens were divided into two batches of 60 specimens each, and were subjected to chilling either with flake ice or slurry ice, respectively. Both batches were stored in an isothermal room at $+2^{\circ} \mathrm{C}$. Fifteen specimens were taken from each batch on days $1,3,5$ and 7 of chilled storage and divided into three groups $(n=3)$ of five specimens each that were studied separately to carry out the statistical analysis. Once the specimens had been subjected to sensory analyses, the edible flesh was separated and used to undertake both the microbiological and biochemical analyses.

\section{$\underline{\text { Sensory analyses }}$}

These were conducted by a taste panel consisting of five experienced judges, based on traditional guidelines for freshness assessment in marine species (Table 1$)^{21}$. Carapace, eyes, gills, odour and flesh were evaluated, these allowing the classification of the lobster specimens in one of the following four categories: E (extra), A (good), B (acceptable) and non-admitted (rejected).

\section{$\underline{\text { Microbiological analyses }}$}

Samples of $25 \mathrm{~g}$ of muscle were dissected aseptically from chilled lobster specimens, mixed with $225 \mathrm{ml}$ of $0.1 \%$ peptone water (Oxoid Ltd., London, UK), and homogenised in a stomacher (Seward Medical, London, UK). Serial dilutions from the microbial extracts were prepared in $0.1 \%$ peptone-water. Total aerobes and 
psychrotrophic bacteria were investigated in Plate Count Agar (PCA, Oxoid) after incubation at $30^{\circ} \mathrm{C}$ for $48 \mathrm{~h}$ or at $7-8^{\circ} \mathrm{C}$ for 10 days, respectively, as previously described $^{22,23}$. Lactose-fermenting Enterobacteriaceae (coliforms) were investigated in Violet Red Bile Agar (VRBA medium, Merck, Darmstadt, Germany), following the manufacturer's instructions ${ }^{24}$. The results were expressed as log CFU g ${ }^{-1}$ muscle.

\section{Biochemical analyses}

The evolution of $\mathrm{pH}$ values in lobster muscle was determined by means of a 6mm diameter insertion electrode (Crison, Barcelona, Spain).

The $\mathrm{NaCl}$ content in lobster muscle was calculated from the amount of chloride by boiling in $\mathrm{HNO}_{3}$ with excess $\mathrm{AgNO}_{3}$, followed by titration with $\mathrm{NH}_{4} \mathrm{SCN}^{25}$. Results

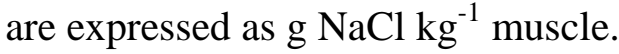

The water content was determined by the difference in weight of the homogenised muscle (1-2 g) before and after heating at $105^{\circ} \mathrm{C} / 24 \mathrm{~h}$. The results were expressed as g water $\mathrm{kg}^{-1}$ muscle.

The lipid fraction was extracted according to the Bligh and Dyer ${ }^{26}$ method. The results were calculated as g lipids $\mathrm{kg}^{-1}$ muscle.

Nucleotide extracts were prepared according to the method of $\operatorname{Ryder}^{27}$ and were stored at $-30^{\circ} \mathrm{C}$ until analysis. Analysis was carried out according to Aubourg et al. ${ }^{28}$. The K value (\%) was calculated according to the following molar concentration ratio, in which the different molecules involved in the adenosine-triphosphate degradation pathway are considered: $\mathrm{K}$ value $(\%)=100 \mathrm{x}$ (hypoxanthine+inosine)/(adenosinetriphosphate+adenosine-diphosphate+adenosine-monophosphate+inosinemonophosphate+inosine+hypoxanthine). 
Total volatile base-nitrogen (TVB-N) values were measured by the Antonacopoulos $^{29}$ method, with the modifications described elsewhere ${ }^{30}$. The results were expressed as mg TVB- $\mathrm{N} \mathrm{kg}^{-1}$ muscle.

Trimethylamine-nitrogen (TMA-N) values were obtained by the picrate method, as previously described ${ }^{31}$. The results were expressed as mg TMA- $\mathrm{N} \mathrm{kg}^{-1}$ muscle.

Free fatty acid (FFA) contents were determined in lipid extracts by the Lowry and Tinsley ${ }^{32}$ method, based on complex formation with cupric acetated-pyridine. The results were expressed as g FFA kg-1 lipids.

Non-enzymatic browning (NEB) development was determined at $420 \mathrm{~nm}$ in the lipid extract resulting from the edible flesh ${ }^{33}$. The results were calculated using the following formula: $\mathrm{NEB}=\mathrm{A} \times \mathrm{V} / \mathrm{w}$, where $\mathrm{A}$ is the absorbance value at $420 \mathrm{~nm}, \mathrm{~V}$ denotes the volume (ml) of the sample, and $\mathrm{w}$ is the amount (mg) of the lipid sample.

\section{$\underline{\text { Statistical analyses }}$}

Data from the different sensorial, microbiological and biochemical analyses were subjected to one-way analysis of variance $(\mathrm{p}<0.05)$ to assess differences between both chilling conditions; further, data were also subjected to one-way analysis of variance $(\mathrm{p}<0.05)$ to assess differences during storage time for each chilling condition. In both cases, the comparison of means was accomplished using a least-significant difference (LSD) method ${ }^{34}$. The SPSS software (SPSS Inc., Chicago, IL, USA) was also used to explore the statistical significance $(\mathrm{p}<0.05)$ of the differences between batches, this including multivariate contrasts and multiple comparisons. 


\section{RESULTS AND DISCUSSION}

\section{$\underline{\text { General composition and } \mathrm{pH}}$}

The water content of lobster muscle ranged between 765 and $810 \mathrm{~g} \mathrm{~kg}^{-1}$ muscle while the lipid content was in the 5.0-6.5 $\mathrm{g} \mathrm{kg}^{-1}$ muscle range. The differences in both constituents among specimens may be explained in terms of individual variations rather than being due to chilled storage or chilling conditions. Both constituents (water and lipids) exhibited values similar to those reported for lean fish species ${ }^{16,28}$, but showed a lower lipid content and a higher water content, when compared to values described for fatty fish species ${ }^{3,17}$.

The presence of $\mathrm{NaCl}$ in the chilling medium, characteristic of the slurry ice system, led to a significant increase $(\mathrm{p}<0.05)$ of the $\mathrm{NaCl}$ content in the lobster muscle in the slurry ice batch as compared to the flake ice batch (Table 2). This finding is in agreement with a previous study performed with sardine ${ }^{17}$.

$\mathrm{pH}$ exhibited a remarkable increase $(\mathrm{p}<0.05)$ at day 5 for both chilling conditions (Table 2). Significant differences $(\mathrm{p}<0.05)$ between both batches were only obtained on day 3, a higher $\mathrm{pH}$ value being determined in the flake ice batch. Previous studies on fish species have also reported lower $\mathrm{pH}$ values in the muscle of aquatic food products stored in slurry ice as compared to traditional flake ice ${ }^{35,36}$. These results strongly suggest a limited occurrence of both endogenous and microbial alkalinising mechanisms involved in the spoilage of fish.

\section{$\underline{\text { Microbiological analyses }}$}

The evolution of microbial growth in lobster muscle along chilled storage in the slurry ice and flake ice is shown in Figures 1 and 2. As can be seen for both bacterial 
groups investigated, the use of slurry ice involved significantly $(\mathrm{p}<0.05)$ lower counts for both microbial parameters. Thus, with respect to total aerobes the average differences between batches were $1.03 \log \mathrm{CFU} \mathrm{g}^{-1}$ muscle and $1.45 \log \mathrm{CFU} \mathrm{g}{ }^{-1}$ muscle on days 5 and 7 of storage, respectively (Figure 1), the slurry ice batch exhibiting lower microbial counts than the flake ice batch. However, although microbial growth was slowed down in the slurry ice batch, the aerobe counts did not reach figures higher than $10^{5} \mathrm{CFU} \mathrm{g}{ }^{-1}$ muscle, suggesting that microbial spoilage was not a limiting factor to sensory acceptability, as will be discussed below.

The counts of aerobes in lobster muscle stored in slurry ice did not vary significantly $(\mathrm{p}<0.05)$ during the first three days of storage, as determined by the Tukey test. This result was also observed in the flake ice batch, and clearly indicated that the microbiological breakdown of lobster would not reach an intense rate until, at least, the fifth day of storage in any of the two storage batches considered. Other studies have also reported significantly lower bacterial in shrimp stored in slurry ice, as compared with conventional flake ice ${ }^{19}$. Likewise, storage in slurry ice also leads to a significant slowing down of microbial growth in aquatic food products other than crustaceans, such as turbot ${ }^{14}$, horse mackerel ${ }^{37}$, hake ${ }^{35}$ and sardine ${ }^{36}$.

With respect to the psychrotrophes, the numbers of this bacterial group were also significantly $(\mathrm{p}<0.05)$ lower in the slurry ice batch than in the flake ice batch after three days of storage, a result that would underline a better microbiological control of the latter system on the microbial activity in lobster muscle (Figure 2). Thus, the psychrotrophes in the flake ice batch reached average counts 1.34 log CFU/g and 1.88 $\log$ CFU/g higher than in the slurry ice after 5 and 7 days of storage, respectively (Figure 2). The counts of psychrotrophes in lobster muscle, as in the case of aerobes, did not vary significantly $(\mathrm{p}<0.05)$ during the first stages of storage (days 0 -3) in slurry 
ice, according to the Tukey test. Such result was also observed in the flake ice batch and provided evidence that the numbers of psychrotrophes would not increase significantly $(\mathrm{p}<0.05)$ in lobster muscle until, at least, day five of storage, regardless the storage system employed. These results confirm previous studies performed on aquatic food products other than crustaceans, such as sardine ${ }^{36}$, and underline the potential usefulness of slurry ice-based storage systems to slow down the growth of psychrotrophic bacteria.

It should also be mentioned that in our work coliform counts were generally below $10^{2} \mathrm{CFU} \mathrm{g}{ }^{-1}$ muscle in both batches, except for one specimen from the flake ice batch in which a $1.1 \times 10^{3} \mathrm{CFU} \mathrm{g}^{-1}$ muscle concentration was determined on day 5 . Oneway ANOVA revealed that the use of slurry ice kept coliform counts comparable to the initial figures seen at the beginning of storage. In any case, this bacterial group exhibited a limited development in lobster, this being in agreement with previous works with other studies such as sardine ${ }^{36}$ and jack mackerel ${ }^{38}$.

\section{Biochemical analyses}

Nucleotide autolytic degradation was studied by means of the $\mathrm{K}$ value (\%) (Figure 3). Both icing conditions led to increases $(\mathrm{p}<0.05)$ in the $\mathrm{K}$ value during storage, in agreement with previous research on fish chilled under different conditions ${ }^{16,17,28}$. In the present work, flake ice treatment elicited significantly higher $(p<0.05)$ values than that performed with slurry ice, such that an inhibitory effect of slurry ice on the nucleotide degradation pathway can be inferred for lobster muscle. The increases with time in the $\mathrm{K}$ value were slow for both chilling conditions, in agreement with previous work on crustacean species ${ }^{39}$, and $\mathrm{K}$ values were found to be lower than those obtained for fish species under similar conditions ${ }^{16,17,28}$. 
Regarding the assessment of TVB-N, a slight increase $(\mathrm{p}<0.05)$ was observed for both chilling systems along the time of storage (Figure 4). The initial material value (281.6 \pm 9.1 ) proved to be higher than that obtained for fish species ${ }^{35,36}$, and agreed to previous research on crustacean species ${ }^{3,39,40}$. Comparison of both chilling systems only indicated significant differences at the end of the experiment, in the sense that higher $(\mathrm{p}<0.05)$ values were obtained for the flake ice treatment. Both chilling conditions provided a lower development than other crustacean species under flake ice conditions $^{40,41}$.

TMA-N content increased $(\mathrm{p}<0.05)$ with the time of storage time in lobster muscle stored in flake ice (Figure 5). In contrast, storage in slurry ice did not lead to significant ( $p>0.05$ ) differences during the experiment. As expected, the initial values in the starting material (42.6 \pm 5.6$)$, as in the case of TVB-N, were higher than for fish species $^{35,36}$, and agreed to previous research on crustacean species ${ }^{3,41}$. Comparison of both chilling systems disclosed significant differences in the TMA-N contents at the end of the experiment, a lower $(\mathrm{p}<0.05)$ value being obtained for lobster muscle stored in slurry ice. Flake ice treatment of lobster led to higher TMA-N levels than in the case of other crustacean species stored under flake ice conditions ${ }^{40}$.

Lipid hydrolysis was determined according to the assessment of FFA (Table 2). The evolution of FFA contents during storage under each chilling system indicated an important increase in the 5-7 day period. Comparison of both chilling systems did not reveal differences $(\mathrm{p}>0.05)$ during the 0-3-day initial period. However, slowing down of lipid hydrolysis mechanisms was observed after 5-7 days of storage in the slurry ice batch. This difference may be due not only to the lower storage temperature of the slurry ice batch, but also to the fact that lipid hydrolysis may be progressively inhibited as the $\mathrm{NaCl}$ content increases in lobster muscle stored in slurry ice (Table 2). In this 
sense, the inhibition of FFA formation by $\mathrm{NaCl}$ during the processing of marine species has been documented previously ${ }^{17,42,43}$.

The development of non-enzymatic browning (NEB) reactions increased significantly $(\mathrm{p}<0.05)$ in both batches as storage time progressed (Table 2). Comparison of both chilling systems indicated a significantly $(\mathrm{p}<0.05)$ more intense browning in lipid extracts from lobster muscle stored in slurry ice during the early stages of storage (1-3 days). However, no significant $(\mathrm{p}>0.05)$ differences between batches were observed after this period. The enhancement of NEB development at days 1 and 3 in the slurry ice batch may be explained in terms of the higher $\mathrm{NaCl}$ content of lobster muscle as a consequence of storage. Thus, although the presence of $\mathrm{NaCl}$ may be regarded as positive as regards microbial spoilage and FFA formation, its effect on lipid oxidation and non-enzymatic browning development has been found undesirable $e^{44,45}$.

\section{$\underline{\text { Sensory analysis }}$}

Different attributes were analysed and compared between both batches. The scores obtained for both chilling conditions are presented in Table 3. For both batches, decreasing $(\mathrm{p}<0.05)$ scores in all attributes were obtained as the storage time progressed. In general terms, both chilling systems led to shelf life periods of 3 days. However, the results were different depending on the attribute considered. Thus, the appearance of the eyes, gills and the odour obtained better scores in the slurry ice batch than in the flake ice batch. In contrast, the assessment of carapace appearance elicited a better score for specimens belonging to the flake ice batch. The evaluation of flesh did not reveal significant ( $>0.05$ ) differences between batches (Table 3).

The differences observed between attribute scores may be explained as a result of the relative predominance of different spoilage mechanisms in each batch. Thus, 
detrimental changes in odour and gills are mainly related to microbial spoilage and autolytic degradation mechanisms. Both spoilage mechanisms proved to be slowed down in lobster muscle stored in slurry ice, as concluded from the microbial (aerobes and psychrotrophs) and biochemical (K value, TVB-N, TMA-N and FFA) analyses. In this sense, slurry ice afforded a better protection of lobster meat against these spoilage mechanisms. However, a more intense browning was observed in the carapace of lobster specimens stored in slurry ice, indicating a more intense melanin formation in this batch. In this sense, a detrimental effect of slurry ice in lobster quality was observed as a result of enhancement of the enzymatic browning pathway, leading to important quality losses in sensory acceptability ${ }^{11,46}$.

\section{CONCLUDING REMARKS}

Quality loss during chilled storage of Norway lobster was assessed according to microbiological and biochemical indices and sensory evaluation. The predominance of different spoilage mechanisms in each batch was checked, revealing different limiting factors during the chilled storage of this crustacean species. When compared to flake ice, according to the corresponding microbial and biochemical parameters evaluated storage in slurry ice involved a significant reduction in microbial growth and autolytic degradation. However, owing to the presence of $\mathrm{NaCl}$ in the chilling medium an enhancing effect of slurry ice on enzymatic browning reactions (carapace appearance) and non-enzymatic browning formation (lobster muscle) were observed. On the basis of profiting from the already known advantages of slurry ice systems and obtaining a better overall maintenance of quality and an extended shelf life for lobster and other 
crustacean species, further research focused on the employment of slurry ice in the absence of $\mathrm{NaCl}$ and/or combined with anti-melanosis agents is envisaged.

\section{ACKNOWLEDGEMENTS}

The authors wish to thank KINARCA S.A.U. for providing the slurry ice equipment. This work was supported by the Secretaría Xeral de I+D from the Xunta de Galicia (Galicia, Spain) (Project PGIDTI02RMA18E). The authors also thank Mr. Marcos Trigo and Mrs. Mónica García for their excellent technical assistance. 


\section{FIGURE LEGENDS}

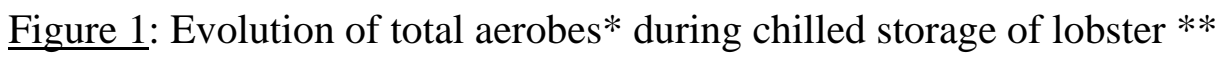

* Results are expressed as $\log$ CFU $\mathrm{g}^{-1}$ muscle. Mean values (n=3) and standard deviations are given.

** Chilling systems: Flake ice (FI) and slurry ice (SI).

Figure 2: Evolution of psychrotrophs* during chilled storage of lobster**

* Results are expressed as $\log$ CFU $\mathrm{g}^{-1}$ muscle. Mean values (n=3) and standard deviations are given.

** Chilling systems as in Figure 1.

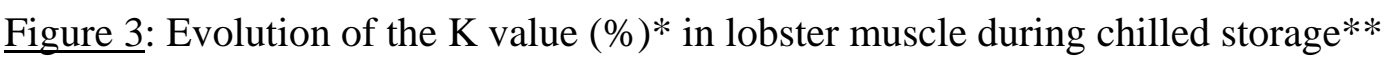

* Results are expressed in percentage as the ratio of nucleotide concentrations, as described in the text. Mean values $(n=3)$ and standard deviations are given.

** Chilling systems as in Figure 1.

Figure 4: Determination of total volatile base-nitrogen (TVB-N) content* in lobster muscle during chilled storage**

* Results are expressed as mg TVB-N kg-1 muscle. Mean values ( $\mathrm{n}=3$ ) and standard deviations are given.

** Chilling systems as in Figure 1. 
Figure 5: Determination of trimethylamine-nitrogen (TMA-N) content* in lobster muscle during chilled storage**

* Results are expressed as mg TMA-N kg ${ }^{-1}$ muscle. Mean values $(n=3)$ and standard deviations are given.

** Chilling systems as in Figure 1. 


\section{REFERENCES}

1 FAO Inform, Fishery statistics. Capture production, in Food and Agriculture Organization of the United Nations, Rome (Italy). Yearbook 2002, vol 94, pp 58-59 (2004).

2 Cheftel $\mathrm{J}$ and Cheftel H, Introducción a la bioquímica y tecnología de alimentos, Acribia, Zaragoza (Spain), vol 1, pp 237-318 (1976).

3 Piclet G, Le poisson aliment. Composition et intérêt nutritionnel. Cah Nutr Diét XXII: 317-335 (1987).

4 Whittle K, Hardy R and Hobbs G, Chilled fish and fishery products, in Chilled foods. The state of the art, Ed by Gormley T. Elsevier Applied Science, New York (USA), pp 87-116 (1990).

5 Simpson B, Marshall M and Otwell W, Phenoloxidases from pink and white shrimp: kinetic and other properties. J Agric Food Chem 35: 918-921 (1987).

6 Ashie I, Smith J and Simpson B, Spoilage and shelf-life extension of fresh fish and shellfish. Crit Rev Food Sci Nutr 36: 87-121 (1996).

7 Mendes R, Quinta R and Nunes $\mathrm{M}^{\mathrm{a}} \mathrm{L}$, Changes in baseline levels of nucleotides during ice storage of fish crustaceans from Portuguese coast. Eur Food Res Technol 212: 141-146 (2001).

8 Kraus L, Refrigerated sea water treatment of herring and mackerel for human consumption, in Pelagic fish. The resource and its exploitation, Ed by Burt J, Hardy R and Whittle K. Fishing News Books, Aberdeen, Scotland (UK), pp 7381 (1992). 
9 Ruiz-Capillas C and Moral A, Free amino acids in muscle of Norway lobster (Nephrops norvegicus) in controlled and modified atmospheres during chilled storage. Food Chem 86: 85-91 (2004).

10 Xiong S, Xiong Y, Blanchard S, Wang B and Tidwell J, Evaluation of tenderness in prawns (Machrobrachium rosenbergii) marinated in various salt and acid solutions. Int J Food Sci Technol 37: 291-296 (2002).

11 McEvily A, Iyengar R and Otwell S, Sulfite alternative prevents shrimp melanosis. Food Technol 45(9): 80, 82-86 (1991).

12 Piñeiro C, Barros-Velázquez J and Aubourg S, Effects of newer slurry ice systems on the quality of aquatic food products: a comparative review versus flake-ice chilling methods. Trends Food Sci Technol 15: 575-582 (2004).

13 Huidobro A, Mendes R and Nunes M, Slaughtering of gilthead seabream (Spaurus aurata) in liquid ice: influence on fish quality. Z Lebensm Unters Forsch 213: 267-272 (2001).

14 Rodríguez Ó, Barros-Velázquez J, Piñeiro C, Gallardo J and Aubourg S, Effects of storage in slurry ice on the microbial, chemical and sensory quality and on the shelf-life of farmed turbot (Psetta maxima). Food Chem. In press. Publied on line (DOI: 101016 j.foodchem.2004.11.0504) (2005).

15 Price R, Melvin E and Bell J, Postmortem changes in chilled round, bled and dressed albacore. J Food Sci 56: 318-321 (1991).

16 Losada V, Piñeiro C, Barros-Velázquez J and Aubourg S, Effect of slurry ice on chemical changes related to quality loss during European hake (Merluccius merluccius) chilled storage. Eur Food Res Technol 219: 27-31 (2004). 
17 Losada V, Barros-Velázquez J, Gallardo J and Aubourg S, Effect of advanced chilling methods on lipid damage during sardine (Sardina pilchardus) storage. Eur J Lipid Sci Technol 106: 844-850 (2004).

18 Chinivasagam H, Bremner $\mathrm{H}$, Wood A and Nottingham S, Volatile components associated with bacterial spoilage of tropical prawns. Int J Food Microb 42: 4555 (1998).

19 Huidobro A, López-Caballero M and Mendes R, Onboard processing of deepwater pink shrimp (Parapenaeus longirostris) with liquid ice: effect on quality. $Z$ Lebensm Unters Forsch 214: 469-475 (2002).

20 FAO Inform, Fishery statistics. Capture production, in Food and Agriculture Organization of the United Nations, Rome (Italy). Yearbook 2002, vol 94, pp 309-310 (2004).

21 Council Regulations (EC) No 2406/96, 26 November 1996. Off J Eur Commun L334/2:23.12 (1996).

22 Ben-Gigirey B, Vieites J, Villa T and Barros-Velázquez J, Changes in biogenic amines and microbilogical analysis in albacore (Thunnus alalunga) muscle during frozen storage. J Food Prot 61: 608-615 (1998).

23 Ben-Gigirey B, Vieites J, Villa T and Barros-Velázquez J, Histamine and cadaverine production by bacteria isolated from fresh and frozen albacore (Thunnus alalunga). J Food Prot 62: 933-939 (1999).

24 Merck Microbiology Manual. Merck, Darmstadt (Germany), p 273 (2000).

25 AOAC: Official methods of analysis of the Association of Analytical Chemistry. $15^{\text {th }}$ ed., p. 870 (1990).

26 Bligh E and Dyer W, A rapid method of total extraction and purification. Can $J$ Biochem Physiol 37: 911-917 (1959). 
27 Ryder J, Determination of adenosine triphosphate and its breakdown products in fish muscle by high performance liquid chromatography. J Agric Food Chem 33: 678-680 (1985).

28 Aubourg S, Piñeiro C, Gallardo J and Barros-Velázquez J, Biochemical changes and quality loss during chilled storage of farmed turbot (Psetta maxima). Food Chem 90: 445-452 (2005).

29 Antonacopoulos N, Verbesserte apparatus zur quantitativer destillation wasserdampfflühtiger stoffe. Z Lebensm Unters Forsch 200: 252-255 (1960).

30 Aubourg S, Sotelo C and Gallardo J, Quality assessment of sardines during storage by measurement of fluorescent compounds. J Food Sci 62: 295-298, 304 (1997).

31 Tozawa H, Erokibara K and Amano K, Proposed modification of Dyer’s method for trimethylamine determination in cod fish, in Fish Inspection and Quality Control, Ed by Kreuzer R. Fishing News Books Ltd, London (UK), pp 187-190 (1971).

32 Lowry R and Tinsley I, Rapid colorimetric determination of free fatty acids. J Am Oil Chem Soc 53: 470-472 (1976).

33 Aubourg S, Medina I and Pérez-Martín R, A comparison between conventional and fluorescence detection methods of cooking-induced damage to tuna fish lipids. $Z$ Lebensm Unters Forsch 200: 252-255 (1995).

34 Statsoft, Statistica for macintosh; Statsoft and its licensors, Tulsa, Oklahoma (USA) (1994).

35 Rodríguez Ó, Losada V, Aubourg S and Barros-Velázquez J, Enhanced shelf-life of chilled European hake (Merluccius merluccius) stored in slurry ice as determined by sensory analysis and assessment of microbiological activity. Food Res Internat 37: 749-757 (2004). 
36 Campos C, Rodríguez Ó, Losada V, Aubourg S and Barros-Velázquez J, Effects of storage in ozonised slurry ice on the sensory and microbial quality of sardine (Sardina pilchardus). Int J Food Microb. In press. Publied on line (DOI: 10.1016 j.ijfoodmicro.2004.11.039) (2005).

37 Rodríguez Ó, Losada V, Aubourg S and Barros-Velázquez J, Sensory. Microbial and chemical effects of a slurry ice system on horse mackerel (Trachurus trachurus). J Sci Food Agric. In press. Publied on line (DOI: 10.1002/jsfa.1960) (2005).

38 Figueroa G, Galeno H, Troncoso M and Aguilera J, Analysis of the microbial flora of jack mackerel (Trachurus murphyi) minced products. Sci Alim 10: 907-912 (1990).

39 Mendes R, Huidobro A and López-Caballero E, Indole levels in deepwater pink shrimp (Parapenaeus longirostris) from the Portuguese coast. Effects of temperature abuse. Eur Food Res Technol 214: 125-130 (2002).

40 Iyengar J, Visweswaria $\mathrm{H}$, Moorjant $\mathrm{M}$ and Bhatia D, Assessment of the progressive spoilage of iced-stored shrimp. J Fish Res Board Can 17: 475-485 (1960).

41 López-Caballero M E, Gonçalves A and Nunes, ML, Effect of $\mathrm{CO}_{2} / \mathrm{O}_{2}$-containing modified atmospheres on packed deepwater pink shrimp (Parapenaeus longirostris). Eur Food Res Technol 214: 192-197 (2002).

42 Refsgaard H, Brockhoff P and Jensen B, Free polyunsaturated fatty acids cause taste deterioration of salmon during frozen storage. J Agric Food Chem 48: 32803285 (2000).

43 Aubourg S and Ugliano M, Effect of brine pre-treatment on lipid stability of frozen horse mackerel (Trachurus trachurus). Eur Food Res Technol 215: 91-95 (2002). 
44 Maruf F, Ledward D, Neale R and Poulter R, Chemical and nutritional quality of Indonesian dried-salted mackerel (Rastrelliger kanagurta). Int J Food Sci Technol 25: 66-77.

45 Smith G, Hole M and Hanson S, Assessment of lipid oxidation in Indonesian salteddried marine catfish (Arius thalassinus). J Sci Food Agric 51: 193-205.

46 Chen J, Charest D, Marshall M and Wei C, Comparison of two treatment methods on the purification of shrimp polyphenol oxidase. J Sci Food Agric 75: 12-18 (1997). 
TABLE 1. Scale employed for evaluating the sensory quality of chilled lobster

\begin{tabular}{|c|c|c|c|c|}
\hline \multirow[t]{2}{*}{ Attribute } & \multicolumn{4}{|c|}{ Category } \\
\hline & $\mathbf{E}$ & A & B & Rejected \\
\hline Carapace & $\begin{array}{l}\text { Pink-orange and } \\
\text { bright; without } \\
\text { black spots }\end{array}$ & $\begin{array}{c}\text { Pink-orange and } \\
\text { pale; without } \\
\text { black spots }\end{array}$ & $\begin{array}{c}\text { Incipient } \\
\text { formation of } \\
\text { brown spots }\end{array}$ & $\begin{array}{l}\text { Important } \\
\text { formation of } \\
\text { brown spots }\end{array}$ \\
\hline $\begin{array}{l}\text { Eyes and } \\
\text { gills }\end{array}$ & $\begin{array}{l}\text { Black and bright } \\
\text { eye; pink gills }\end{array}$ & $\begin{array}{c}\text { Black and } \\
\text { lustreless eye; } \\
\text { incipiently grey } \\
\text { gills }\end{array}$ & $\begin{array}{l}\text { Grey eye; dark- } \\
\text { grey gills }\end{array}$ & $\begin{array}{c}\text { Grey eye; green- } \\
\text { grey gills }\end{array}$ \\
\hline Odour & $\begin{array}{l}\text { Sharp seaweed } \\
\text { and shellfish }\end{array}$ & $\begin{array}{l}\text { Weak seaweed } \\
\text { and shellfish }\end{array}$ & $\begin{array}{c}\text { Slightly sour and } \\
\text { putrid }\end{array}$ & Sour and putrid \\
\hline Flesh & $\begin{array}{c}\text { Transparent; } \\
\text { blue-white } \\
\text { coloured }\end{array}$ & $\begin{array}{c}\text { Not transparent; } \\
\text { blue-white } \\
\text { coloured }\end{array}$ & $\begin{array}{l}\text { Opaque and } \\
\text { lustreless }\end{array}$ & $\begin{array}{l}\text { Opaque and } \\
\text { incipient } \\
\text { browning }\end{array}$ \\
\hline
\end{tabular}


TABLE 2. Results of biochemical analyses (NaCl; pH; free fatty acids, FFA; nonenzymatic browning, NEB)* in chilled lobster**

\begin{tabular}{|c|c|c|c|c|c|c|c|c|}
\hline \multirow{2}{*}{$\begin{array}{c}\text { Chilling } \\
\text { Time } \\
\text { (days) }\end{array}$} & \multicolumn{2}{|c|}{ NaCI } & \multicolumn{2}{c|}{ pH } & \multicolumn{2}{c|}{ FFA } & \multicolumn{2}{c|}{ NEB } \\
\cline { 2 - 9 } & FI & SI & FI & SI & FI & SI & FI & SI \\
\hline Initial & ${ }^{\mathrm{z}} 4.56$ & ${ }^{\mathrm{z}} 4.56$ & ${ }^{\mathrm{y}} 7.05$ & ${ }^{\mathrm{y}} 7.05$ & ${ }^{\mathrm{zy}} 10.68$ & ${ }^{\mathrm{z}} 10.68$ & ${ }^{\mathrm{z}} 1.93$ & ${ }^{\mathrm{z}} 1.93$ \\
\hline 1 & $(0.11)$ & $(0.11)$ & $(0.05)$ & $(0.05)$ & $(0.97)$ & $(0.97)$ & $(0.29)$ & $(0.29)$ \\
\hline 3 & ${ }^{\mathrm{zy}} 4.30 \mathrm{a}$ & ${ }^{\mathrm{yx}} 6.97 \mathrm{~b}$ & ${ }^{\mathrm{zy}} 6.95$ & ${ }^{\mathrm{y}} 6.99$ & ${ }^{\mathrm{y}} 12.43$ & ${ }^{\mathrm{y}} 12.39$ & ${ }^{\mathrm{y}} 3.69 \mathrm{a}$ & ${ }^{\mathrm{y}} 7.87 \mathrm{~b}$ \\
& $(0.61)$ & $(1.76)$ & $(0.23)$ & $(0.36)$ & $(1.24)$ & $(0.25)$ & $(0.46)$ & $(1.79)$ \\
\hline 5 & ${ }^{\mathrm{zy}} 4.63 \mathrm{a}$ & ${ }^{\mathrm{y}} 6.20 \mathrm{~b}$ & ${ }^{\mathrm{z}} 6.85 \mathrm{~b}$ & ${ }^{\mathrm{z}} 6.69 \mathrm{a}$ & ${ }^{\mathrm{z}} 10.66$ & ${ }^{\mathrm{z}} 10.45$ & ${ }^{\mathrm{x}} 11.59 \mathrm{a}$ & ${ }^{\mathrm{x}} 22.89 \mathrm{~b}$ \\
& $(0.99)$ & $(0.19)$ & $(0.10)$ & $(0.01)$ & $(0.73)$ & $(0.74)$ & $(2.84)$ & $(7.72)$ \\
\hline 7 & $(0.13)$ & $(0.74)$ & $(0.14)$ & $(0.31)$ & $(7.11)$ & $(1.15)$ & $(7.61)$ & $(4.76)$ \\
\hline & ${ }^{\mathrm{z}} 4.30 \mathrm{a}$ & ${ }^{\mathrm{w}} 10.70 \mathrm{~b}$ & ${ }^{\mathrm{zy}} 7.18$ & ${ }^{\mathrm{y}} 7.11$ & ${ }^{\mathrm{x}} 30.72 \mathrm{~b}$ & ${ }^{\mathrm{x}} 17.66 \mathrm{a}$ & ${ }^{\mathrm{w}} 28.96$ & ${ }^{\mathrm{x}} 27.21$ \\
& $(0.56)$ & $(0.98)$ & $(0.29)$ & $(0.11)$ & $(4.17)$ & $(3.01)$ & $(4.21)$ & $(2.54)$ \\
\hline
\end{tabular}

* Mean values of three independent determinations $(n=3)$; standard deviations are indicated in brackets. For each analysis and at each storage time, means followed by different letters $(a, b)$ indicate significant differences $(p<0.05)$ between both chilling systems. For each column, mean values preceded by different superscripts $(z, y, x, w)$ indicate significant $(\mathrm{p}<0.05)$ differences as a result of chilling time for each icing system.

** Chilling systems: Flake ice (FI) and Slurry ice (SI). Units employed: $\mathrm{g} \mathrm{kg}^{-1}$ muscle for $\mathrm{NaCl}$ and FFA contents; NEB development was calculated as expressed in the Materials and Methods section. 
TABLE 3. Sensory acceptability* of chilled lobster**

\begin{tabular}{|c|c|c|c|c|c|c|c|c|}
\hline \multirow{2}{*}{$\begin{array}{c}\text { Chilled } \\
\text { storage time } \\
\text { (days) }\end{array}$} & \multicolumn{2}{|c|}{ Carapace } & Eyes and gills & \multicolumn{2}{c|}{ Odour } & \multicolumn{2}{c|}{ Flesh } \\
\cline { 2 - 9 } & FI & SI & FI & SI & FI & SI & FI & SI \\
\hline 1 & A & A & E & E & A & A & A & A \\
\hline 3 & A & B & A & A & B & A & A & A \\
\hline 5 & B & Rejected & B & A & Rejected & B & A & A \\
\hline 7 & Rejected & Rejected & B & B & Rejected & Rejected & B & B \\
\hline
\end{tabular}

* Freshness categories as expressed in Table 1. All lobster specimens exhibited an initial "E" quality for all attributes evaluated. For each attribute and at each storage time, a different category for flake and slurry ices indicates a significant difference $(\mathrm{p}<0.05)$.

** Chilling system abbreviations as expressed in Table 2. 